\title{
STUDIES ON DIGESTIVE ORGANS OF TWO SEA TURTLES, Chelonia mydas $L$. and Eretmochelys imbricata $L$.
}

\author{
( Nyoman S. Nuitja*) and Silvia Wijaya*)
}

\begin{abstract}
The digestive organs of two sea turtles, Chelonia mydas $L$. and Eretmochelys imbricata $L$. with purpose to analyse the digestive tract and other organs, also to preform their weight were carapace length relation skimp. The specimens of the two species were obtained from slaughtered houses in Benoa Bay, South Bali. The carapace length and carapace width, showed a significant correlation. The number of nipples composition in esophagus of the two species was different. There was very strong correlation between esophagus length and the number of nipples.
\end{abstract}

KEYWORD: $\quad$ internal digestive, Chelonia mydas L., Eretmochelys imbricata L., nipples, folds, and esophagus

\section{INTRODUCTION}

Since many years ago some biologists were involves studied in various aspects of sea turtles such as the behavior, nest temperature, migration, etc. But the macroanatomy study is lack, especially of the digestive tract is poorly known. A tendency that the structural in the digestive tract is difference by species. This paper has much more deeply studied as a measurement region of internal relief of digestive tract and relative growth of sea turtles landed at Benoa, South Bali. Recently, the fishermen have performed a movement to catch the turtles as far as in safety. Although the islands of Kalimantan, Sulawesi and Maluku have great deal of turtles living, but local governments have strictly banned the hunt. That is why, fishermen mostly hunt in the other areas such as East Java around Blambangan, Sukamade and Bailing, West Java around Cikepuh, Pangumbahan, Cipatujah and Flores.

Sea turtles were caught by fisherman and slaughtered commonly in Bali, mostly containing of $\mathrm{C}$. mydas even $E$. imbricata sporadically. Both these have regulation by National Government law.

The slaughtered animals particularly at south Bali, were going continuous from time to time. This is problem in Indonesia, where the restocking is nothing in Bali. The fishermen are always moving hunt the turtles. Along this study, the turtle hunting at fishing grounds. Catching by the turtles is more simple, if this animal come ashore to lay which is beaches of West Java and East Java. This beach is a part of Natural Reserve as Cikepuh in West Java and Sukamade in East Java.

Studies sea turtles anatomy is important and the first time occurred in Indonesia. The purposes of this study are to analyze the digestive tract and other organs, also to perform their weight-carapace length relationship. Other purposes of this study are to know 1) The position of internal organs; 2) The actual position by partial structure of digestive tract; and 3 ) The proportion between part of digestive tract and length of the carapace.

\section{MATERIALS AND METHODS}

Turtles samples were randomly collected at the Benoa bay, South Bali. The turtles unloaded from the ships, were used for the samples. Each sample has mark number for identification along operation. Turtles were captured in shallow waters of reeflat, nesting grounds of Blambangan. At Tanjung Benoa in Benoa bay there are slaughtered houses, and Sidekarye is other one, having two slaughtered houses. Before operation, the turtles were weighted and measured for the Straight Carapace Length and Straight Carapace Width.

Statistical procedure follows Snedecor and Cochran (1967) and statistical significance is set at the $5 \%$ level. All calculations were done on log transformcd data, except linear regressions of of digestive tract and other parameters of the turtles. The general condition of turtle body was checked out when any parasite still on the body. The color of carapace and any damage of cornea or sclera checked out. Before section, the turtle put on its back, the plastron faced upward and their legs were tied tightly. Autopsy knife was pierced into the troad till turtle died. Then along the place between carapace and outer plastron plate was thrusted with the autopsy knife. An incision was made through the skin along the edge of anterior and posterior of plastron. The plastron was discarded from the muscle beneath. Then some incisions were made along the border of lateral muscle mass on the edge of carapace. And then where the muscle and pectoral circle could be lifted and pushed toward the head until the heart and viscera were visible. The

Division of Waters Resource Management, Marine and Fisheries Faculty, Bogor Agriculture Institute-Bogor 
muscle could be discarded by skin articulation at the joint. A centrally ventral incision was made to separate the left and right pelvic, then followed by lifting the pelvic upward and backward by disarticulation of femur. Then the muscle masswas carefully separated from the pericardium, peritoneum and the viscera without disturbing oilier organs. Next the position of organs was examined. Pleuroperitonium cavity is commonly contained moisture. And this moisture is obstructs the lungs, urogenital, tract, and all the moisture was eliminated. The lungs are pink, attack to back and bordered by back bone. When the disgestive tract has been taken and opened, the structure of organ of this tract was seen. Any part of the digestive tract was scutinily measured to get more accurate data.

\section{RESULTS AND DISCUSSION}

\section{Measurement of Slaughtered Turtles}

Measurements of slaughtered turtles are summarized in Table I. The relationships between Straight Carapace Length and Weight of turtles in both of sex are high significant. Table I, show a significant positive linear correlation between Straight Carapace Length and Straight Carapace Width, both for all sexes. That is meant to pointed out where grow the carapace length is linear with grow carapace width. The most significants of these data are from Sidekarye I and Sidekarye || stations. The turtles caught by fishermen around East Java, Blambangan inshore and little number from Pangumbahan area. Most of turtles slaughtered consist of females than males. At Tanjung Benoa station, sex ratios $1.5: 1$, it means that the females are 1.5 times of males slaughtered at Tanjung Benoa station. But from Sidekarye I and Sidekarye II stations, sex ratios are very sharp, it is $3: 1$ of Sidekarye 1 and $4: 1$ of Sidekarye II. It means that each 5 or 6 samples of slaughtered turtles is composed by one male $C$. mydas $L$. These ratios composition were caught along of Flores island and other from East Java, including around Blambangan inshore.

\section{The Whole Organs an the Body}

At first, cutting shallowly through the skin and ventral muscles of the neck along the inner margins of the lower jaw and posterior along the midline to the plastron exposes the trachea 1) and esophagus; 2) on the right side, the pectoral girdle limb, removed by first cutting the skin along the anterior margin of the carapace dorsal to the limb and severing the lateral attachments of the pectoral muscles along the carapace margins. Then, while lifting the posterior tip of the coracoid toward the head, the dorsal attachments of the pectoral muscles were cut at the surface of the carapace.The shoulder joint was disarticulated and girdle removed leaving the limb in place. Removing the girdles distrub the position of the major of the heart; 3) and adjacent of it as liver; and 4 ), the lobes may be pused ventrally along the ventral septum. The ventral peritoneum, a connective tissue sheet covering the body cavity was cut interiorly and pulled back to expose the digestive tract $(6,7$, and 8$)$, also bladder (9), and spleen (10). The esophagus (2) extends dorsally into the body and turns left under theheart (3) to joint the stomach (6). The expanded, anterior protein of the stomach continues posterior along the left margin of the body, narrows, gradually, then turns back on itself to joint the intestine ( 7 and 8 ). Then tinously straight to rectum and anus (11). The urinary bladder (9) rests ventral to the entry of the intestine into the cloaca. The dorsoventrally flattended bronchi enter the lungs near their anterior medial margins and continue posterior through the lung tissue giving branches at right angles and gradually decreasing in diameter. The lungs are attached dorsally to the carapace lining over most of their area. The paired ovaries (Figure 1) in these immature animal are inconspicuous, elongate, membranous structures attached to the dorsal, peritoneum posterior to the lungs. The paired undeveloped oviducts are fine, white tubes attached to the peritoneum by a transparent ribbon of connective tissue. Tile oviducts extend inside the cloaca.

Figure 2 show the dimension of the digestive tract of sea turtles. As the other vertebrates, the turtle's digestive tract is placed in the center of the body

Table 1. Regression in the form $Y=a+b X$

\begin{tabular}{ccccccccc}
\hline No. & Station & $\mathbf{X}$ & $\mathbf{Y}$ & Intercept & Slope & $\mathbf{R}$ & $\mathbf{N}$ & Sex \\
\hline 1. & TB-I & SCL & SCW & 2.716 & 0.512 & 0.81 & 22 & 0 \\
& & SCL & SCW & 6.518 & 0.583 & 0.89 & 15 & $\delta$ \\
2. & TB-II & SCL & SCW & 7.287 & 0.917 & 0.92 & 4 & n.a \\
3. & SK-I & SCL & SCW & 1.815 & 0.819 & 0.97 & 32 & 0 \\
& & & SCW & 1.633 & 0.873 & 0.96 & 11 & $\delta$ \\
4. & \multirow{2}{*}{ SK-II } & SCL & SCW & 1.966 & 0.976 & 0.98 & 32 & 0 \\
& & & SCW & 0.761 & 0.849 & 0.96 & 8 & $\delta$ \\
\hline
\end{tabular}

Note: $\quad X=$ Straight Carapace Length (SCL)

$Y=$ Straight Carapase Width (SCW)

Legend: All samples were composed by C. mydas, except from TB of 4 samples Hawksbill. 


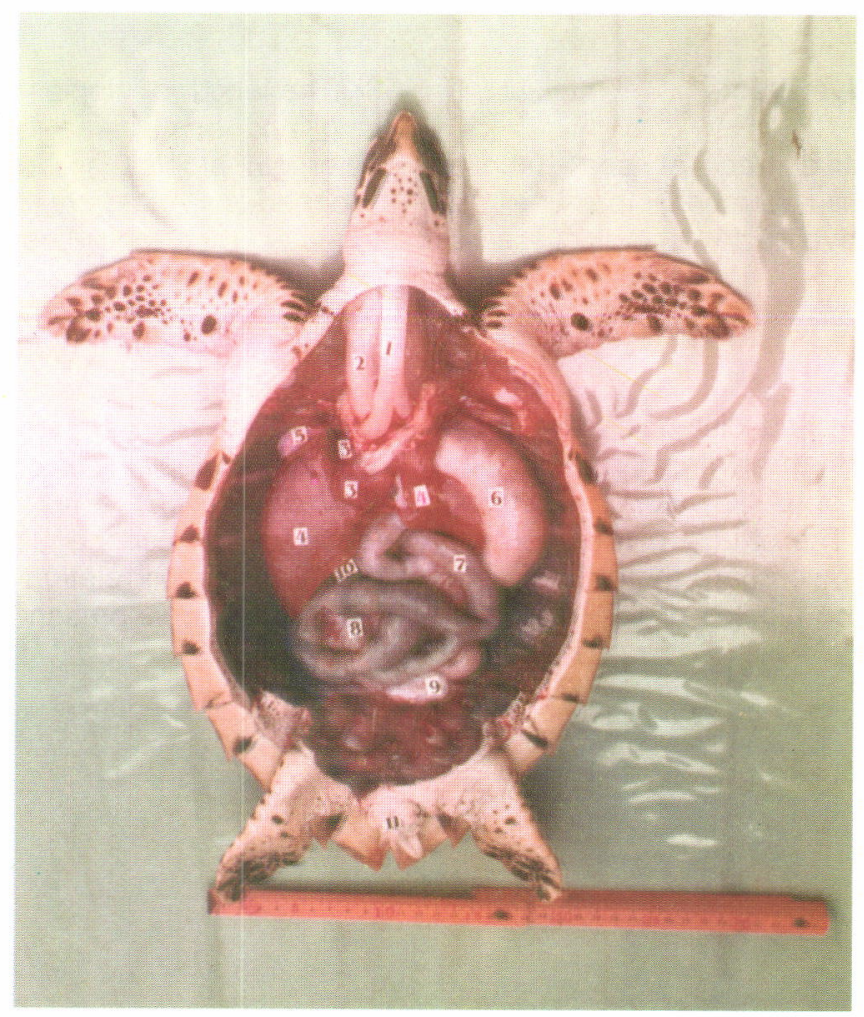

Figure 1. Position of ovaries in cavity body.

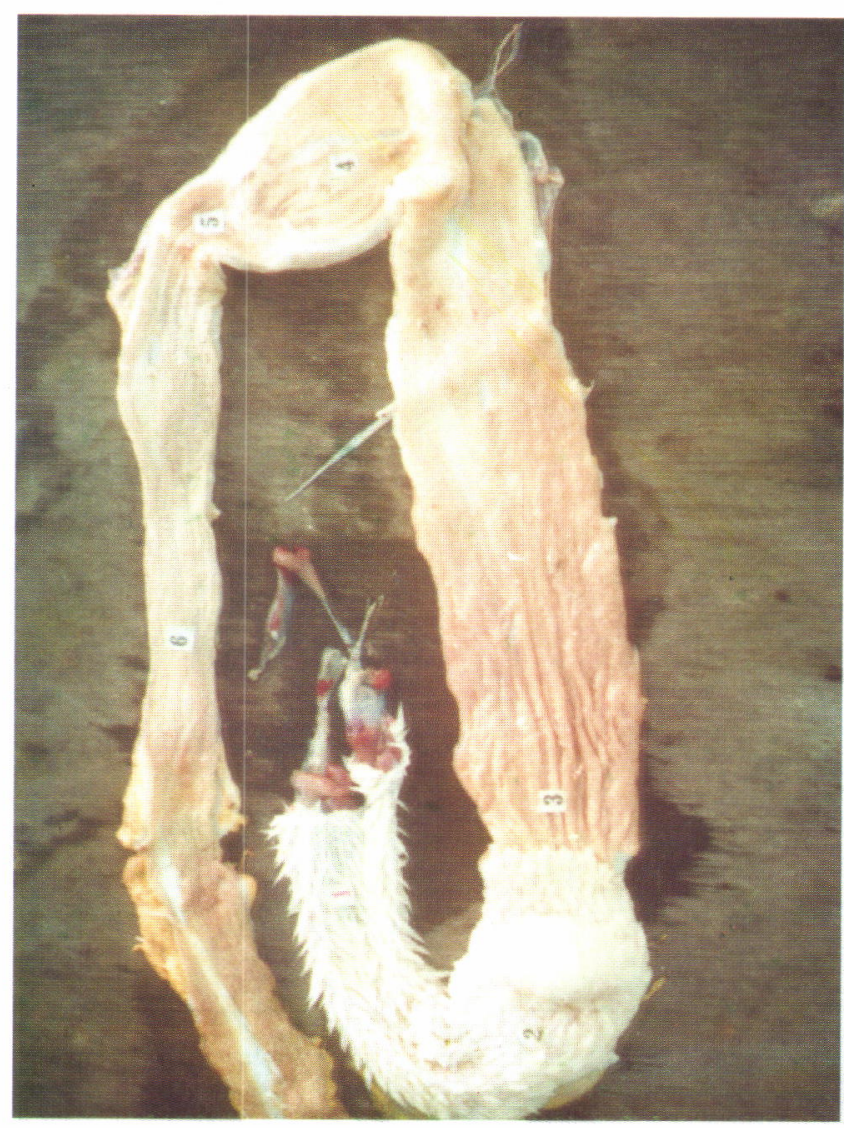

Note:

Figure 2

Dimension of digestive tract.

1. Long nipples on an anterior esophagus

2. Short nipples on posterior esophagus

3. Longitudinal folds from stomach $(3,4)$, pyloric (5), and intestine (6) 


\section{Internal Relief of Digestive Tract}

Generally, the digestive tract of sea turtle is composed by esophagus, stomach, intestine and rectum. Any part of digestive tract will be discussed as follow.

\section{Structure of Esophagus}

In general, the esophagus is distensible that it can accommodate anything that the turtles can get into the mouth. The esophagus of $C$. mydas $L$. has long, conical, cornified nipple. The structure of esophagus comprises protuberances like sharp thorns and nails. Parts of scientist call it the nipples or papilla (Figure
3). The length of nipples is irregular. Some nipples are long and some are short event rudimentary. This heterogin nipples are observed at the anteriorly of esophagus. Anteriorly these nipples are so close together that their basses touch and are entirely cornified. Near the stomach the nipple end. The esophagus of both species has nipples usually have a single point. Table 2 shows nipples data presented for both species. At an anterior, esophagus contains 18 to 20 nipples per $\mathrm{cm}$ square and remaining 5 to 6 of long sizes nipples per $\mathrm{cm}$ square. Nipples number of $E$. imbricata $L$. are less than that $C$. mydas $L$. The longer of the esophagus, follows by more the nipple present. The correlation of length of esophagus and number of nipple present show the linea.

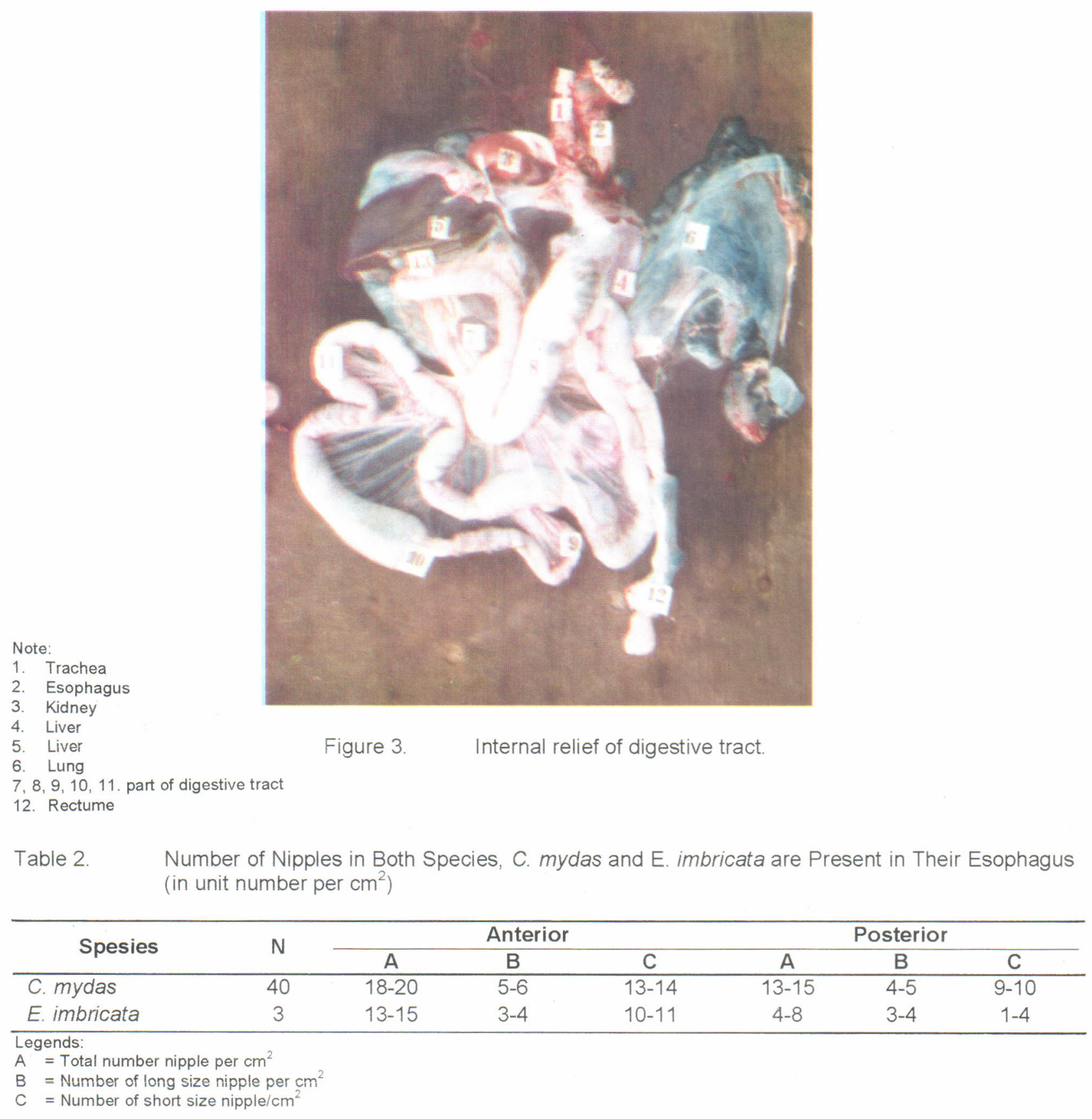


$r$ regression $Y=9.76+1.38 \times(N=16)$

where:

$r=0.98$. It means that the bigger is the turtle has the longer of the esophagus.

\section{Stomach}

The majority of vertebrates has a storage sac (stomach). The stomach is an organ concerned with both storage and digestion food. The pattern of stomach relief is consistentwith large, broader, unbranched, parallel longitudinal folds. Anteriorly, the stomach is an expanded, thick wall sac, with a smooth lining. In general, the stomach is divided into three regions that are cardiac, fundus and body. The opening from esophagus into stomach is called the cardiac. The wall of the stomach form is a dome shaped. The region of transition of stomach into intestine is called the pylorus. The cardiac and fundus of sea turtle are fairly. Their cavity is blow up and lies between the cardiac wall on the left and fundus wall on the other side. Posterior, in direction of pyloric canal, it is getting small. Both the turtles $C$ mydas $L$ and $E$. imbriocata $L$. their stomach $U$ form, parallel longitudinal folds. The folds are regular and straight but convulated at the cardiac their surface membrane is usually smooth straight and the wall between folds is flat.

\section{Intestines}

Part of digested food is absorbed through the walls of intestines and passes into blood, which carries it to tissues of the organs. Both the turtles, their intestines begin from pyloric to rectum. The intestine of this specimen is a tube going from the pyloric to an acutes curvature. However, there is subdivision of this region, that there are accordingly to Warren (1959). The anterior is a bigger and following by longest narrow diameter of the tube and then normally one. The intestine of the turtle is relatively longest than other regions and composed by longitudinal folds. These folds are coiled but rarely branch. The usual pattern in an intestine is one of zigzag folds which are normally very thin and parallel sided. The intestine contains wavy folds of various diameter, they are close together and parallel.

\section{Rectum}

The folds of the rectum are coarse and not so deep than the other regions. This rectum mostly black color wall, and near end of digestive tract become a little broad. In this region, undigested food is dominated as feces. It is usually 2.0 to $4.5 \mathrm{~cm}$ in length.

\section{Composition Length of Part Digestive Tract}

Table 3 shows the composition region of digestive trtact. In general, that composition is mostly composed by intestine which is lonest region. These region are consisting $90 \%$ or more than all the canal length.

\section{Straight Carapace Length Digestive Tract Length Relationship}

As known that the specimens along parallel by the size of turtles are follow the length of digestive tract. Table 4 some linear regression is presented for each digestive tract, where the significant relationship occurred. The carapace size of turtles slaughtered has ranging 40.0 to $48.5 \mathrm{~cm}$ for $C$. mydas $L$. and 32.1 to $49.6 \mathrm{~cm}$ for E. imbricata L. Growth studies on sea turtles in nature are rare, But Mendoca's (1981) recapture of Loggerheads in 50 to $75 \mathrm{~cm}$ in length. It is indicated their mature in 10 to 15 years.Limpus's (1979) recaptures of sub adult Loggerheads of carapace length 76 to $88 \mathrm{~cm}$, showed they are growing at a lower rate than Mendoca's smaller turtles. Balazs (1979) noted that growth rates of Hawaian Green turtle avarage 0.08 to 0.44 permonth over periods of to 37 months in the wild. Beside that, the body cavity of turtles slaughtered mostly females because that containing in one male of 4 to 5 animals. It is meant that might be the turtles population of the inshore mostly consisting the females. The esophagus of both species is with sharply solid nipples and different in length. Burne (1905) agreed that thje nipples in Dermochelys coriacea $L$. are much longer than those in $C$. mydas $L$. The large nipples in $D$. coriacea $L$. average $4.0 \mathrm{~cm}$ in length. But the present study that the $C$. mydas $L$.in which all the nipples are about 0.5 to $2.0 \mathrm{~cm}$ in length. Most of nipples are longest on anterior but rarely at posterior. The main

Table 3. The Composition Length of Region is Part of Digestive Tract of Sea Turtles Collecting in Bali in unit \%

\begin{tabular}{llcccccc}
\hline \multicolumn{1}{c}{ Station } & Spesies & $\mathrm{N}$ & Esophagus & Stomach & Pylorus & Intestine & Rectum \\
\hline TB I & C. mydas & 37 & 3.17 & 4.17 & 0.35 & 91.35 & 0.39 \\
TB II & E. imbricata & 4 & 4.08 & 4.38 & 0.49 & 90.47 & 0.58 \\
SK & & & & & & & \\
I+II & C. mydas & 43 & 3.38 & 3.95 & 0.26 & 92.02 & 0.39 \\
\hline
\end{tabular}


function of nipples to crush all the food materials. Anteriorly these nipples are so close together that their bases touch and are entirely cornified. The food of sea turles is mainly composed by various diets including some seaweeds, microcrustaceans, protozoan, small fishes, mollusks, etc. The stomach is a large pouch where is stored and some digestion occurs. Anteriorly the stomach is an expanded, thick walled sac with a smooth lining. The stomach narrows and its muscular wall thins posterior. Of both species, there is no obvious muscular value at the pylorus separating the stomach and intestine. However, there is a distinct change in texture from the broad longitudinal folds of the stomach, fine zigzag folds in the intestine. The pattern of stomach relief is consistent broader, unbranched, parallel longitudinal folds. Burne (1905) stated that in D. coriacea $L$., the tubular stomach is divided into compartments by approximately irregular, transverse folds. In Chelonia mydas $L$. has thick, cushion like folds starting about the cardiac and extending posterior as wavy longitudinal folds. According to Botha (1958) that folds eventually fade into a smooth surface membrane. In the intestine, only the longitudinal folds are seen. These folds are coiled but they rarely branch. Eretmochelys imbricata $L$., is similar except that the longitudinal folds are more numerous, much taller and narrower than in C. mydas $L$. The intestine along slender tube, folded arcoiled, is the portion where absorption is completed and undigested residues are formed into feces for expulsion through the cloaca, which ends with the anus

\section{ACKNOWLEDGEMENTS}

The author is grateful to the staff of Bali Wildlife Conservation (Seksi Perlindungan Hutan dan
Pelestarian Alam) Direktur Jenderal Kehutanan for the permission and assistance in sample collection around South Bali.

\section{REFERENCES}

Balazs, G. 1979. growth, food sources, and migrations of immature Hawaii in Chelonia. Hawaii Institute of Marine Biology. In IUCN/SSC of Marine Turtle Newsletter. No.10: 3pp

Botha, G. S. M. 1958. Note on the comparative anatomy of the cardio esophageal junction. Acta, Anal. 39: 52-84.

Burne, R. H. 1905. Notes on the muscular and vascular anatomy of the turtle, Dermochelys coriacea L. Proc.Zoo. Soc.London. 29I-324.

Limpus, C. G. 1979. Notes on growth rates of wildturtles. In National Park and Wildlife Service of Queensland. Marine Turtle Newsletter, No.10, IUCN/SSC: $3-5$

Mendoca, M. T. 1981. Comparative growth rates of wild mature Chelonia mydas $L$. and Caretta caretta $L$. in Florida. Journal of Herpetology. 15: 447-451.

Snedecor, O. W. \& W. G. Cochron. 1967. Statistical. Sixth Ed. Jowa State Univ. Press. 593 p.

Warren, A. 1959. Texbook of comparative histology. Oxford University Press. N. Y 